\title{
Analisis Karakteristik Perilaku Perjalanan dan Willingness to Walk Penumpang BRT Trans Jateng (Purwokerto-Purbalingga)
}

\author{
Travel Behavior Analysis and Willingness to Walk BRT Passenger Trans Jateng \\ (Purwokerto-Purbalingga)
}

\author{
Cremona Ayu Novita Sari ${ }^{{ }^{*}, \text {, Sulfah Anjarwati }}{ }^{2}$, Besty Afriandini ${ }^{3}$ \\ 1,2,3Program Studi Teknik Sipil Fakultas Teknik, Universitas Muhammadiyah Purwokerto
}

\begin{tabular}{l}
\hline \hline ARTICLE INFO \\
\hline Article history: \\
DOI: \\
10.30595/pspfs.v1i.157 \\
Submitted: \\
July 1, 2021 \\
Accepted: \\
July 22, 2021 \\
Published: \\
Oct 31, 2021
\end{tabular}

Keywords:

Bus Rapid Transit, Characteristics of travel behavior, Willingness to Walk

\begin{abstract}
The increasing need for transportation has prompted the government to provide public transportation to increase mobility and reduce the number of private vehicles. The Department of Transportation of Central Java Province has developed the Trans Jateng BRT (Bus Rapid Transit) mass transportation in the Barlingmascakeb area through activities to improve the Trans Jateng agglomeration transportation service. The BRT that has been operated in the Banyumas area is Corridor 1 on the Purwokerto-Purbalingga route. This study aimed to analyze the characteristics of travel behavior and passengers' willingness to walk. The sampling of the research was random sampling using a questionnaire as the main data collection tool. The results of the discussion of travel behavior in terms of the purpose of the trip were dominated by recreation/shopping and education. The majority of BRT users used public transportation as the mode used before switching to BRT, the connecting mode from home to shelter is dominated by feeders, while from destination to shelter is dominated by walking. The connection distance from the house and from the destination to the shelter is $>400$ meters. Thus, the majority of respondents came from a buffer range of 0-400 meters. Based on willingness to walk, some respondents walk up to a radius of $>400$ meters. It is necessary to add more shelter points if the distance between stopping points does not meet the standards and provide better shelter access, especially by walking or using other integrated public transportation.
\end{abstract}

This work is licensed under a Creative Commons Attribution 4.0 International License.

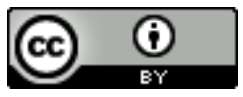

Corresponding Author:

Cremona Ayu Novita Sari

Program Studi Teknik Sipil Fakultas Teknik, Universitas Muhammadiyah Purwokerto

J1 Raya Dukuh Waluh, PO BOX 202 Purwokerto 53182 Telp. (0281) 636751 ext 130

Email: ayucremona@gmail.com

\section{PENDAHULUAN}

Kegiatan transportasi merupakan kebutuhan setiap orang di segala lapisan masyarakat. Meningkatnya jumlah penduduk dan perekonomian di suatu kota mendorong pemerintah setempat untuk meningkatkan kuantitas dan kualitas akan transportasi publik. Dalam pemenuhan kebutuhan mobilitas tersebut diperlukan transportasi publik yang memiliki pelayanan aman, cepat, murah dan efisien guna menunjang kelancaran suatu sistem transportasi perkotaan sehingga mampu menjadi pilihan utama bagi kelompok Captive yang tergantung pada angkutan umum maupun kelompok Choice yang memiliki kendaraan pribadi (Warpani, 2002) dan masyarakat di Indonesia sebagian besar melakukan perjalanan sebagai captive users.

Bus Rapid Transit (BRT) merupakan salah satu angkutan massal berbasis trayek yang menjadi pilihan moda diwilayah perkotaan yang diharapkan dapat meningkatkan daya tarik terhadap angkutan umum guna menekan jumlah penggunaan kendaraan pribadi. Dalam mewujudkan sistem transportasi publik perkotaan tersebut Dinas Perhubungan Provinsi Jawa Tengah telah melakukan pengembangan atau pelayanan angkutan massal BRT Trans Jateng di wilayah 
Barlingmascakeb melalui kegiatan peningkatan pelayanan Angkutan Aglomerasi Trans Jateng salah satunya di wilayah Banyumas yang sudah beroperasional yaitu Koridor 1 Purwokerto-Purbalingga (Renstra Dishub Jateng Tahun 2018-2023).

Berdasarkan hasil evaluasi kinerja BRT Trans Jateng Koridor 1 Purwokerto-Purbalingga secara keseluruhan sudah mencapai Standar Pelayanan Minimum (SPM) maupun World Bank (1986). Tingkat keterisian penumpang (Load factor) sudah mencapai 70\% selain itu indikator lainnya seperti kecepatan perjalanan, waktu tempuh, headway, perpindahan moda dan frekuensi juga sudah memenuhi. Mayoritas pengguna transportasi publik bersifat captive lebih memilih BRT Trans Jateng. Hal ini terlihat pada opsi moda transportasi lain yang akan dipilih penumpang jika BRT terlambat, yaitu tetap menunggu sampai BRT tersebut datang. (Sari \& Afriandini, 2020).

BRT Trans Jateng Koridor 1 ini memiliki potensi yang cukup besar menjadi transportasi publik yang dapat melayani pergerakan masyarakat terutama di wilayah Banyumas dan Purbalingga. Untuk memaksimalkan penggunaan BRT Trans Jateng Koridor 1 Purwokerto-Purbalingga tersebut diperlukan kinerja pelayanan yang optimal. Dengan demikian diperlukan adanya informasi mengenai karakteristik perilaku perjalanan (Marquet et al., 2017) yang terdiri dari data jarak perjalanan hubung ke, moda perjalanan hubung ke, jarak perjalanan hubung dari, moda perjalanan hubung dari, moda sebelum menggunakan bis dan data maksud perjalanan

( Suprayitno \& Ryansyah, 2018).

Willingness to walk merupakan tingkat kesediaan penumpang untuk berjalan kaki dari asal ke halte/shelter untuk mendapatkan angkutan terdekat dengan berjalan kaki dari tempat perhentian akhir menuju tujuan. Dalam pelayanan angkutan umum setidaknya dapat menjangkau seluruh wilayah kota dengan rute layanan bus yang dapat diakses dengan berjalan kaki 200-400 meter (Basuki, 2017 ; Sukor dan Fisal, 2018). Adanya bangkitan dan tarikan di sekitar shelter adalah sangat penting dalam kaitannya dengan tingkat efektif shelter dan operasional penggunaan BRT (Saputri \& Prakoso, 2014).

Berdasarkan beberapa kondisi tersebut, perlu dilakukan analisis mengenai karateristik perilaku perjalanan penumpang BRT ditinjau dari maksud perjalanan, moda sebelum beralih, moda hubung dari rumah ke shelter, moda hubung dari tempat tujuan ke shelter, jarak dari rumah ke shelter, jarak dari tempat tujuan ke shelter dan menganalisis willingness to walk. Hal ini penting dilakukan untuk mengetahui permasalahan dari segi pelayanan angkutan umum BRT sehingga dapat dirumuskan strategi perbaikan untuk membantu meningkatkan kualitas pelayanan yang berkelanjutan pada BRT Trans Jateng Koridor 1 Purwokerto-Purbalingga.

\section{METODE PENELITIAN}

Penelitian ini pada dasarnya merupakan pengumpulan data karakteristik perilaku perjalanan dan Willingness to Walk dari pengguna BRT. Pengumpulan data dilakukan dengan menggunakan survei wawancara kuesioner. Responden dalam penelitian ini adalah penumpang BRT Trans Jateng Koridor 1 Purwokerto-Purbalingga. Tahap pengambilan sampel dalam penelitian ini menggunakan probability sampling yaitu random sampling dimana pengambilan sampel dari anggota populasi yang dilakukan secara acak tanpa memperhatikan stara yang ada dalam populasi tersebut. Hasil wawancara kuesioner diperoleh data sebanyak 200 responden.

Data yang telah diperoleh tersebut akan diolah dengan menggunakan analisis statistik deskriptif untuk menganalisa data dengan cara mendeskripsikan data yang telah terkumpul. Selanjutnya dilakukan identifikasi perilaku perjalanan dengan menggunakan data yang diperlukan berdasarkan data karakteristik terkait sebagaimana Tabel 1 berikut.

Tabel 1. Data Karakteristik Perilaku Perjalanan

\begin{tabular}{cc}
\hline No & Data Karakteristik Perjalanan \\
\hline 1 & Maksud Perjalanan \\
2 & Moda sebelum beralih menggunakan BRT \\
3 & Moda hubung dari rumah ke shelter \\
4 & Moda hubung dari tempat tujuan ke shelter \\
5 & Jarak perjalanan dari rumah ke shelter \\
6 & Jarak perjalanan dari tempat tujuan ke shelter \\
\hline
\end{tabular}

Untuk menganalisa Willingness to Walk hasil dari identifikasi karakteristik perilaku perjalanan berdasarkan jarak dari rumah ke shelter dan jarak dari tempat tujuan ke shelter tersebut kemudian dibandingkan dengan Standar Pelayanan Angkutan Umum Di Indonesia.

\section{HASIL DAN PEMBAHASAN}

\section{Karakteristik Perilaku Perjalanan Penumpang}

Maksud perjalanan

Responden yang diwawancarai dalam penelitian ini memiliki karakteristik perilaku perjalan yang berbeda-beda. Tujuan dilakukan analisa maksud tujuan perjalanan ialah untuk mengetahui perjalanan yang dilakukan tersebut 
merupakan perjalanan yang dilakukan secara rutin atau perjalanan sekali-kali saja sehingga dapat diketahui kebutuhan akan sarana dan prasarananya.

Karakteristik perilaku perjalanan berdasarkan maksud perjalanan sebagian masyarakat merupakan pelaku perjalanan sekali-kali saja dengan melakukan melakukan aktivitas rekreasi/belanja sebesar 28\%, kemudian diikuti dengan aktivitas pendidikan dan lainnya masing-masing sebesar $21 \%$ kemudian aktivitas bekerja sebesar $19 \%$ dan aktivitas berdagang sebesar $11 \%$ sebagaimana Tabel 2 .

Tabel 2. Komposisi Maksud Perjalanan

\begin{tabular}{ccccc}
\hline $\begin{array}{c}\text { Karakteristik } \\
\text { perjalanan }\end{array}$ & Maksud perjalanan & $\begin{array}{c}\text { Responden } \\
\text { Memilih }\end{array}$ & $\begin{array}{c}\text { Prosentase } \\
(\mathbf{\%})\end{array}$ & $\begin{array}{c}\text { Kumulatif } \\
(\mathbf{\%})\end{array}$ \\
\hline Maksud perjalanan & Pendidikan & 42 & $21 \%$ & $21 \%$ \\
& Bekerja & 38 & $19 \%$ & $40 \%$ \\
& Berdagang & 22 & $11 \%$ & $51 \%$ \\
& Rekreasi/ belanja & 56 & $28 \%$ & $79 \%$ \\
& Lainnya & 42 & $21 \%$ & $100 \%$ \\
\hline
\end{tabular}

\section{Moda sebelum beralih ke BRT}

Identifikasi mengenai moda yang digunakan sebelum beralih ke BRT Trans Jateng Koridor 1 bertujuan untuk mengetahui jenis moda apa saja yang biasa digunakan untuk melakukan perjalanan selama ini. Mayoritas pengguna BRT merupakan pengguna kendaraan umum sebesar 43\%, menggunakan kendaraan bermotor sebesar 40\%, mobil pribadi sebesar $10 \%$ dan menggunakan lainnya sebesar $7 \%$ sebagaimana Tabel 3.

Tabel 3. Komposisi Maksud Perjalanan

\begin{tabular}{ccccc}
\hline Karakteristik perjalanan & Moda & $\begin{array}{c}\text { Responden } \\
\text { Memilih }\end{array}$ & $\begin{array}{c}\text { Prosentase } \\
(\boldsymbol{\%})\end{array}$ & $\begin{array}{c}\text { Kumulatif } \\
(\boldsymbol{\%})\end{array}$ \\
\hline Moda sebelum beralih & Kendaraan umum & 86 & $43 \%$ & $43 \%$ \\
& Mobil Pribadi & 20 & $10 \%$ & $53 \%$ \\
& Sepeda motor & 80 & $40 \%$ & $93 \%$ \\
& Lainnya & 14 & $7 \%$ & $100 \%$ \\
\hline
\end{tabular}

\section{Moda perjalanan hubung}

Analisa moda perjalanan hubung bertujuan untuk mengetahui jenis moda apa saja yang digunakan dalam melakukan perjalanan hubung. Dalam penelitian ini moda perjalanan hubung dibagi menjadi dua yaitu dengan berjalan kaki dan menggunakan feeder. Feeder disini merupakan pilihan moda selain berjalan kaki yaitu diantar, menggunakan ojek/becak/taxi dan bus/angkot.

Karakteristik perilaku perjalanan berdasarkan moda perjalanan hubung ke shelter dari rumah ialah dengan berjalan kaki sebesar $45 \%$ dan dengan menggunakan feeder sebesar 55\%. Keadaan seperti ini mengidentifikasikan bahwa sebagian lokasi titik awal responden berada di luar jarak wajar untuk dapat menjangkau lokasi shelter dengan berjalan kaki. Sedangkan karakteristik moda perjalanan hubung dari shelter ke tempat tujuan dengan berjalan kaki sebesar $61 \%$ dan dengan menggunakan feeder sebesar 39\% sebagaimana Gambar 1.

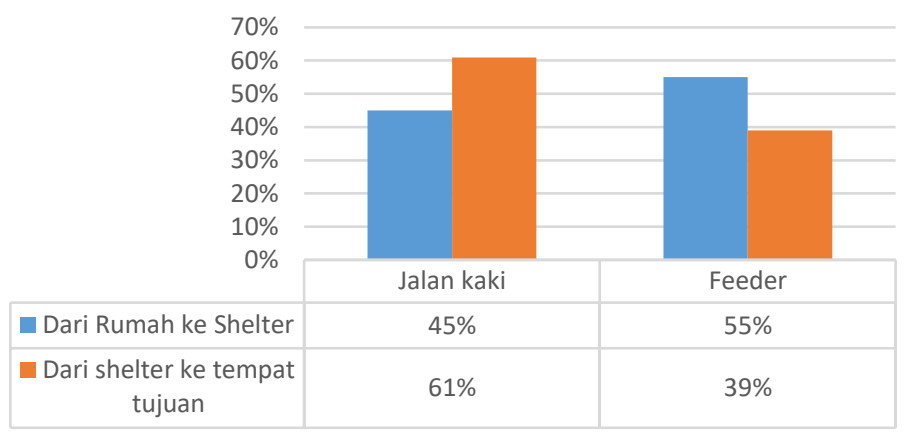

Gambar 1. Moda Perjalanan Hubung

Selanjutnya diketahui bahwa penumpang BRT Trans Jateng Koridor 1 Purwokerto-Purbalingga yang menggunakan feeder ke shelter dari rumah sebanyak 29\% diantar, menggunakan ojek/becak/taxi sebesar $12 \%$ dan 
menggunakan bus/angkot sebesar 14\%. Sedangkan yang menggunakan feeder dari shelter ke tempat tujuan sebanyak $12 \%$ diantar, mengunakan ojek/becak/taxi sebesar 10\% dan menggunakan moda bus/angkot sebesar 17\% sebagaimana Gambar 2.

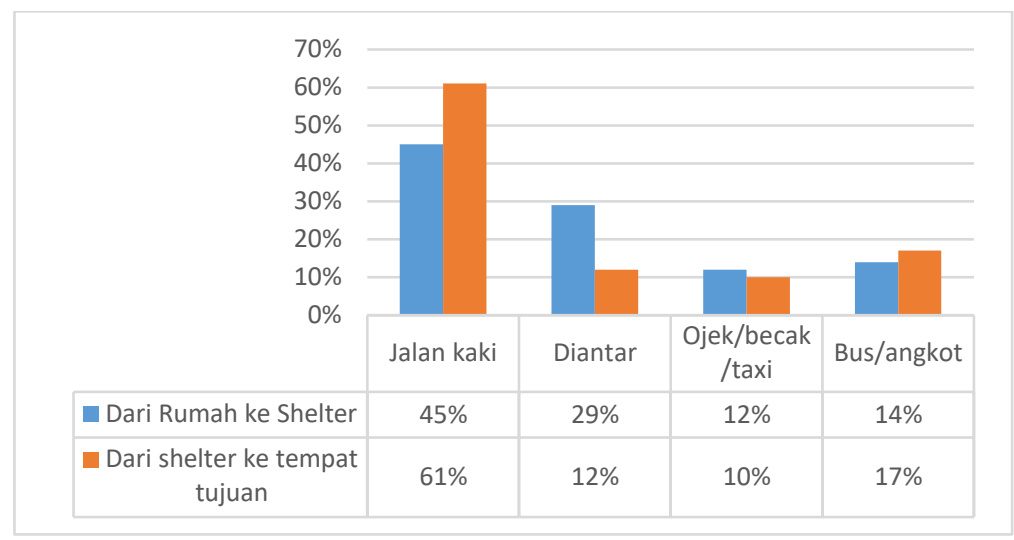

Gambar 2. Moda Transportasi yang Digunakan

\section{Jarak perjalanan hubung}

Secara teoritical untuk berjalan kaki menuju tempat transit berada pada radius 400-800 meter. Selanjutnya jarak berjalan tersebut ditentukan berdasarkan jarak rata-rata berjalan dari rumah ke shelter maupun dari shelter ke tempat tujuan. Untuk jarak <50 meter dari rumah ke shelter sebesar $16 \%$ dan dari shelter ke tempat tujuan sebesar 17\%. Jarak 50-200 meter responden dari rumah ke shelter sebesar 27\% dan dari shelter ke tempat tujuan sebesar 26\%. Jarak 200400 meter dari rumah ke shelter sebesar 16\% dan dari shelter ke tempat tujuan sebesar 18\% seperti Gambar 3.

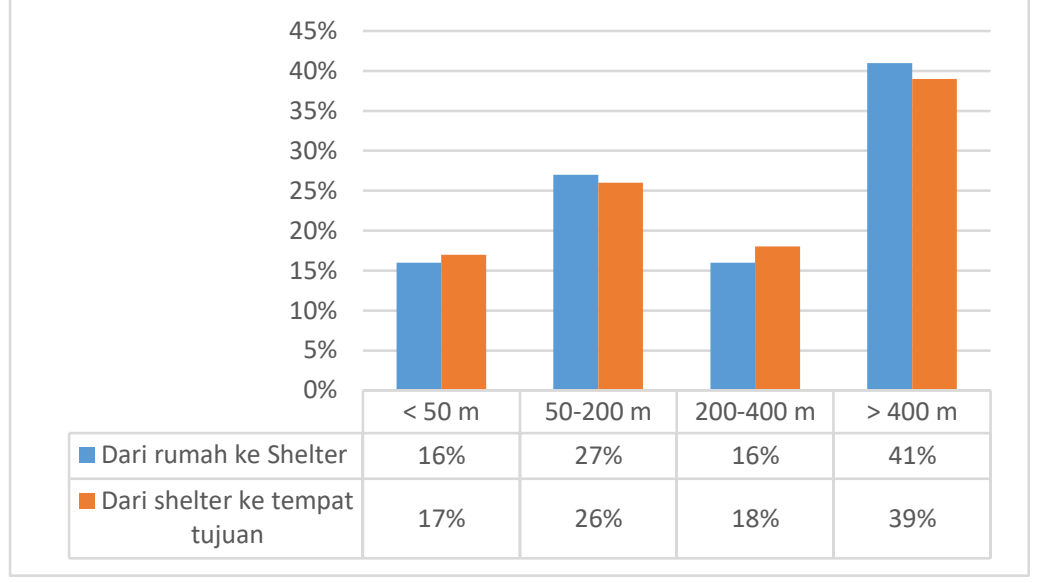

Gambar 3. Jarak Perjalanan Hubung

Dari data tersebut diperoleh bahwa mayoritas penumpang BRT Trans Jateng Koridor 1 Purwokerto-Purbalingga menggunakan moda transportasi berjalan kaki dari rumah ke shelter maupun dari shelter ke tempat tujuan dengan jarak $>400$ meter masing-masing sebanyak $41 \%$ dan 39\%. Jarak perjalanan hubung dari rumah ke shelter sebesar $>400$ meter mayoritas menggunakan feeder. Sedangkan dari shelter menuju tempat tujuan sebesar $>400$ meter mayoritas responden memilih berjalan kaki. Dengan demikian kondisi ini menunjukan bahwa beberapa shelter BRT Trans Jateng Koridor 1 Purwokerto-Purbalingga sudah terjangkau oleh masyarakat menuju ke tempat tujuan.

Jumlah shelter BRT Trans Jateng Koridor 1 Purwokerto-Purbalingga saat ini masih belum cukup dalam mengakomodir kebutuhan masyarakat. Masyarakat kerap mengeluhkan adanya beberapa shelter yang jaraknya terlalu jauh dari tempat tinggal maupun dengan tujuan akhir. Hal ini menjadi salah satu penyebab belum optimalnya penggunaan angkutan umum massal BRT Trans Jateng Koridor 1 Purwokerto-Purbalingga pada beberapa shelter. Oleh karena itu, usulan perbaikan yang dapat dilakukan ialah dengan melakukan penambahan jumlah shelter maupun penyediaan transportasi lainnya yang terintegrasi dengan lokasi shelter terdekat khususnya bagi masyarakat yang memiliki keberadaan di pinggiran kota.

\section{Willingness To Walk (WTW)}

Secara umum willingness to walk penumpang angkutan umum bervariasi tergantung pada karakteristik perilaku perjalanan maupun aksesibilitas dari rumah ke shelter dan dari shelter menuju tempat tujuan. Rute pelayanan angkutan 
umum keseluruh wilayah jaringan trayek tersebut harus juga dapat dijangkau dengan berjalan kaki. Willingness to walk ini nantinya dapat dijadikan sebagai dasar penentuan coverage area di wilayah jangkauan angkutan umum.

Coverage area Trans Jateng Koridor 1 Purwokerto-Purbalingga menjadi salah satu prioritas bagi sebagian besar pengguna BRT dalam menggunakan transportasi publik ini. Dengan adanya aksesibilitas yang tinggi ditunjang keberadaan shelter yang mudah dijangkau oleh masyarakat dengan berjalan kaki tentunya akan berpengaruh terhadap minat pengguna BRT.

Dalam penentuan jarak antar tempat henti menurut Standar Pelayanan Angkutan Umum Di Indonesia melalui Keputusan Direktur Jenderal Perhubungan Darat Nomor: SK. 687/AJ.206/DRJD/2002 berdasarkan kondisi tata guna lahan dan lokasi disajikan pada Tabel 4.

Tabel 4. Standar Jarak Antar Tempat Henti

\begin{tabular}{clcc}
\hline Zona & \multicolumn{1}{c}{ Tata Guna Lahan } & Lokasi & $\begin{array}{c}\text { Jarak Tempat Henti } \\
(\mathbf{m})\end{array}$ \\
\hline 1 & $\begin{array}{l}\text { Pusat kegiatan yang sangat padat dengan tata } \\
\text { guna lahan pasar dan pertokoan }\end{array}$ & Pusat kota & $300-500$ \\
2 & $\begin{array}{l}\text { Campuran jarang; perumahan, ladang, sawah, } \\
\text { tanah kosong }\end{array}$ & Pinggiran kota & $500-1000$ \\
\hline
\end{tabular}

Sumber : Direktorat Jenderal Perhubungan Darat, 2002

Terkait dengan hal tersebut dilakukan identifikasi mengenai kemauan berjalan kaki pengguna BRT Trans Jateng Koridor 1 Purwokerto-Purbalingga yang menunjukan bahwa mayoritas responden bersedia berjalan dengan radius $>400$ meter sebesar $27 \%$ diikuti dengan radius 100 meter sebesar $26 \%$, radius 200 meter sebesar $16 \%$, radius 150 meter sebesar $13 \%$, radius 300 meter sebesar $10 \%$ dan radius 250 meter sebesar $8 \%$ sebagaimana disajikan pada Gambar 4.

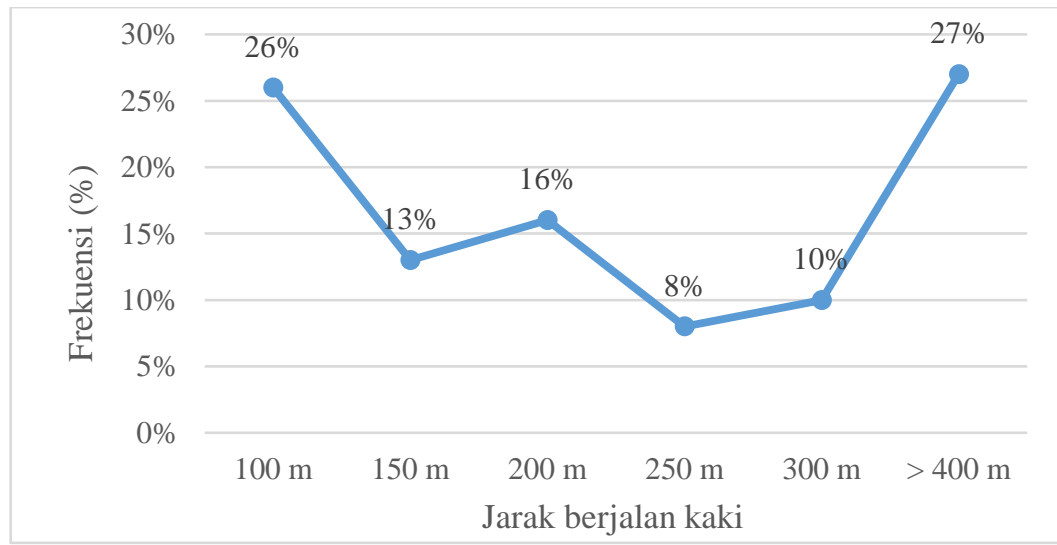

Gambar 4. Willingness to Walk

Berdasarkan dari data willingness to walk dan jarak perjalanan hubung tersebut selanjutnya dibandingkan menurut standar pelayanan dari Direktorat Jenderal Perhubungan Darat tentang penentuan jarak antar tempat henti berdasarkan kondisi tata guna lahan sebagaimana Tabel 4.

Tabel 5. Tabulasi Hasil Perbandingan

\begin{tabular}{ccccc}
\hline \multirow{2}{*}{$\begin{array}{c}\text { Willingness to walk } \\
(\mathbf{m})\end{array}$} & \multicolumn{2}{c}{$\begin{array}{c}\text { Jarak dari rumah ke shelter } \\
(\mathbf{m})\end{array}$} & $\begin{array}{c}\text { Jarak dari shelter ke tempat tujuan } \\
(\mathbf{m})\end{array}$ \\
\cline { 2 - 5 } & Standar & Hasil survei & Standar & Hasil survei \\
\hline$>400$ & $300-500$ & $>400$ & $300-500$ & $>400$ \\
& $500-1000$ & $>400$ & $500-1000$ & $>400$ \\
\hline
\end{tabular}

Sumber: Hasil olah data, 2021 
Menurut standar pelayanan yang baik bahwa jarak yang dibutuhkan pengguna angkutan umum untuk mencapai shelter di pusat kota 300-500 meter dan untuk pinggiran kota ialah antara 500-1000 meter sehingga dari Tabel 5 jarak ke shelter telah memenuhi standar karena sebanyak $41 \%$ memiliki jarak > $400 \mathrm{~m}$. Sedangkan jarak dari shelter ke tempat tujuan juga sudah memenuhi standar karena sebanyak 39\% pengguna BRT memiliki jarak dari shelter ke tempat tujuan sejauh $>400$ meter sehingga berbanding lurus dengan willingness to walk pengguna transportasi publik BRT Koridor 1 Purwokerto-Purbalingga.

Namun disisi lain sebagian responden lainnya hanya mau berjalan kaki pada radius 100 meter hal ini dipengaruhi beberapa faktor salah satunya kebiasaan masyarakat dimana untuk jarak yang tidak terlalu jauh kebanyakan orang malas untuk berjalan kaki maupun lokasi beberapa shelter yang jarak hentinya melebihi standar Standar Pelayanan Minimal dan willingness to walk. Selain itu untuk sebagian masyarakat lainnya yang bersedia berjalan >400 meter diperlukan adanya sarana pendukung yang menunjang aktivitas berjalan kaki yaitu jalur pedestrian yang nyaman dan aman guna meningkatkan aksesibilitas menuju dari/ke shelter.

\section{KESIMPULAN}

Berdasarkan rekapitulasi hasil analisis data survei terhadap penumpang yang melakukan perjalanan dengan menggunakan BRT Trans Jateng Koridor 1 Purwokerto-Purbalingga, dapat ditarik kesimpulan bahwa karakteristik perilaku perjalanan penumpang dalam hal ini maksud perjalanan didominasi oleh rekreasi/belanja dan pendidikan, sebagian besar masyarakat menggunakan kendaraan umum sebagai moda sebelum beralih ke BRT, sedangkan dalam hal moda hubung dari rumah ke shelter didominasi menggunakan feeder (diantar, ojek/becak, taxi dan bus/angkot) dengan jarak hubung > 400 meter sedangkan dari shelter ke tempat tujuan didominasi berjalan kaki dengan jarak hubung > 400 meter. Mayoritas pengguna BRT memiliki Willingness to walk sebesar >400 meter. Perlu adanya penambahan titik shelter apabila jarak antar shelter tidak memenuhi standar jarak antar tempat henti untuk meningkatkan coverage area pada masing-masing shelter khususnya disekitar pemukiman tempat tinggal. Selain itu diperlukan juga penyediaan akses yang lebih baik menuju shelter khususnya dengan berjalan kaki maupun dengan menggunakan transportasi umum lainnya melalui angkutan feeder yang terintegrasi dengan lokasi shelter terdekat sehingga Bus Trans Jateng Koridor 1 Purwokerto-Purbalingga dapat lebih diminati oleh masyarakat.

\section{DAFTAR PUSTAKA}

Basuki, I. (2017). The Willingness to Walk of Urban Transportation Passengers (A Case Study of Urban Transportation Passengers in Yogyakarta Indonesia). Journal of Technology and Social Science (JTSS), 1(3).

Keputusan Direktur Jenderal Perhubungan, Nomor : SK.687/AJ.206/DRJD/2002 Tentang Pedoman Teknis Penyelenggaraan Angkutan Penumpang Umum Diwilayah Perkotaan Dalam Trayek Tetap Dan Teratur. Jakarta

Marquet, O., Bedoya, V. R., \& Miralles-Guasch, C. (2017). Local accessibility inequalities and willingness to walk in Latin-American cities: Findings from Medellín, Colombia. International Journal of Sustainable Transportation, 11(3), 186-196.

Saputri, M. D., \& Prakoso, B. S. E. (2014). Evaluasi Lokasi Eksisting Shelter dan Karakteristik Pengguna Bus Rapid Transit (BRT) Trans-Semarang Pada Dua Koridor Pelayanan di Kota Semarang. Jurnal Bumi Indonesia, 3(3).

Sari, C.A.N \& Afriandini, B. (2020). Evaluasi Kinerja Bus Rapid Transit Trans Jateng Pada Koridor PurwokertoPurbalingga. Sainteks, 17(1), 53-60.

Sukor, N. S. A., \& Fisal, S. F. M. (2018). Factors influencing the willingness to walk to the bus stops in Penang Island. Planning Malaysia, 16(5).

Suprayitno, H., \& Ryansyah, M. (2018). Karakteristik Pelaku dan Perilaku Perjalanan Penumpang Bus Trans Koetaradja. Jurnal Aplikasi Teknik Sipil, 16(2), 55-62.

Warpani, S. P. (2002). Pengelolaan lalu lintas dan angkutan jalan. Penerbit ITB. 